PRECIPITATION ASSESSMENT IN WASTEWATER TREATMENT PLANTS OPERATED FOR BIOLOGICAL NUTRIENT REMOVAL: A CASE STUDY IN

\title{
MURCIA, SPAIN
}

R. Barat ${ }^{\mathrm{a}, *}$, A. Bouzas ${ }^{\mathrm{b}}$, N. Martí ${ }^{\mathrm{b}}, \mathrm{J}$. Ferrer $^{\mathrm{a}}$ and A. Seco ${ }^{\mathrm{b}}$

a Dpto. Ingeniería Hidráulica y Medio Ambiente. Universidad Politécnica de Valencia.

Camino de Vera s/n. 46022 Valencia, Spain

10 b Dpto. Ingeniería Química, Universidad de Valencia. Doctor Moliner, 50. 46100 Burjassot, Valencia, Spain

\footnotetext{
* Corresponding author. Tel.: +34 9638796 18; fax: +34 963877617.

E-mail address: rababa@dihma.upv.es (R. Barat).
} 


\begin{abstract}
Murcia Este Wastewater Treatment Plant is the largest wastewater treatment plant of Murcia (Spain). The plant operators have continuously found pipe blockage and accumulation of solids on equipment surfaces, on the anaerobic digestion and post-digestion processes. This 5 work studies the precipitation problems in Murcia Este Wastewater Treatment Plant in order to locate the precipitation sources and its causes from an exhaustive mass balance analysis. The DAF thickener and anaerobic digester mass balances suggest that the most part of the polyphosphate is released during the excess sludge thickening. Despite the high concentrations achieved in the thickened sludge, precipitation does not occur in this point due

10 to the low $\mathrm{pH}$. The ammonium and $\mathrm{pH}$ increase during the anaerobic digestion provoke that the precipitation takes place mainly inside the digesters and in downstream processes. The $50.7 \%$ of the available phosphate is fixed in the digester: $52.0 \%$ precipitates as ammonium struvite, $39.2 \%$ precipitates as hydroxyapatite and the remaining $8.8 \%$ is adsorbed on the solids surface. Thermodynamic calculations and elemental analysis confirm that potassium

15 struvite does not precipitate in the anaerobic digesters.
\end{abstract}

\title{
Keywords
}

Anaerobic digestion, precipitation, sludge treatment, struvite, wastewater. 


\section{Introduction}

Phosphate is the limiting component for growth in most ecosystems. The discharge of phosphates in surface waters may lead to eutrophication and blooming of algae. Therefore it is essential to control the phosphate emissions. Nowadays, biological phosphorus removal is

5 often the preferred technology to achieve the effluent standards (typically in the range of $\left.0.5-1 \mathrm{gP} / \mathrm{m}^{3}\right)$.

In biological nutrient removal processes (BNR), phosphates and metal cations are taken up and stored as polyphosphates (Poly-P) inside the bacterial cells. These polyphosphates are

10 removed from the system in the excess sludge. During the sludge treatment, especially anaerobic digestion, these Poly-P are released to the liquid phase (Wild et al., 1997) increasing significantly the phosphate concentration in the system. Moreover, the concentration of other ions also increases in the digester: soluble magnesium concentration mainly increases due to Poly-P hydrolysis and ammonium concentration increases as protein

15 is degraded. The hardness of the influent wastewater also controls the precipitation processes of phosphorus inside the digester since determines $\mathrm{Ca}^{+2}$ and $\mathrm{Mg}^{+2}$ concentration in the wastewater. The increase in the concentrations of dissolved components and the high $\mathrm{pH}$ achieved during anaerobic digestion increase the phosphorus precipitation potential in this stage of the treatment system. Different magnesium and calcium phosphates are likely to 20 precipitate in the sludge treatment system causing significant operational problems. Accumulation of struvite $\left(\mathrm{MgNH}_{4} \mathrm{PO}_{4} \cdot 6 \mathrm{H}_{2} \mathrm{O}\right)$ on pipe walls and equipment surfaces of anaerobic digestion and post-digestion processes has been reported as a frequent problem in the wastewater treatment industry (Ohlinger et. al., 1998). 
Dewatering of the anaerobic digested sludge by centrifugation was found to be a critical stage for precipitation in many wastewater treatment plants in Germany (Heinzmann and Engel, 2005). The solid formed was mainly struvite and small portions of different calcium phosphate compounds. Downstream of the centrifugation of the sludge, precipitation was so 5 significant that the outgoing pipes were fully blocked.

Struvite precipitation is not simply a problem of BNR treatment works (Parsons and Doyle, 2004). However, Enhanced Biological Phosphorus Removal (EBPR) processes, which produce a Poly-P rich waste sludge, exacerbate struvite and calcium phosphate deposit 10 problems in anaerobic sludge digestion. Therefore, in these cases, special attention must be paid to control the formation of these deposits.

Precipitation problems lead to an important increase in the cost of the sludge management operations (Neethling and Benish, 2004). Furthermore, these precipitation processes can be

15 very important in the recycled streams composition from the sludge treatment causing variations in the dissolved phosphorus concentration that might affect the efficiency of the EBPR process.

The aim of this work is to study the precipitation problems in a large scale wastewater treatment plant in order to locate the precipitation sources and its causes from an exhaustive mass balance analysis. This work is the first step before the proposal of solutions trying to minimize the uncontrolled precipitation. 


\section{Materials and methods}

This study has been performed in Murcia Este Wastewater Treatment Plant (WWTP) in order to determine the type and extent of phosphate fixation in the waste activated sludge line.

\section{$5 \quad 2.1$ Murcia Este WWTP}

Murcia Este WWTP was established in 2000 and is the largest treatment plant of Murcia (Spain), with a capacity of $100000 \mathrm{~m}^{3} / \mathrm{d}$. The water line consists in an activated sludge process operated for biological nitrogen and phosphorus removal ( $\mathrm{A}_{2} \mathrm{O}$ configuration) following preliminary treatment and primary sedimentation. The water line consists of three

10 identical lines divided in anaerobic, anoxic and aerobic zones each one. In each line the anaerobic, anoxic and aerobic zones are divided into five, three and four compartments, respectively, with a total volume of $41405 \mathrm{~m}^{3}$ (6429 $\mathrm{m}^{3}$ anaerobic, $4850 \mathrm{~m}^{3}$ anoxic and 30146 $\mathrm{m}^{3}$ aerobic).

15 The primary and the secondary excess sludges are concentrated in two gravity thickeners and two dissolved air flotation (DAF) thickeners respectively. Once thickened, both sludges are mixed before being anaerobically digested. The anaerobic digestion is carried out in three digesters of $6103 \mathrm{~m}^{3}$ per unit. The digested sludge is stored in a secondary digester and finally dewatered by centrifugation. The effluents from centrifuges and sludge thickeners are recycled to the water line before the primary settler.

The plant operators have continuously found precipitation problems in the sludge line, especially during anaerobic digestion and post-digestion processes, which caused pipe blockage and accumulation on the surfaces of different devices of the sludge management system as centrifuge, pumps and digested sludge or supernatant pipes (Figure 1). 


\subsection{Analytical campaign}

To identify the precipitation problems an intensive analytical campaign was carried out under normal operation conditions in different points of the sludge line. Figure 2 shows the WWTP configuration with the sampling points marked with grey dots. The influent sludge line

5 composition to the anaerobic digestion (line 8) was obtained from the mass balance between the primary thickened sludge (line 4) and the excess floated sludge (line 7). Each line was sampled four times through two weeks. The parameters analysed were: total suspended solids, volatile suspended solids, total phosphorus, phosphate, ammonium, alkalinity, $\mathrm{pH}$ and total and soluble concentrations of calcium, magnesium and potassium. All the analyses were

10 carried out according to the Standard Methods (APHA, 1998). Furthermore, the flow rates were measured in all the sludge lines sampled.

\subsection{Mass balance}

Phosphorus, potassium, magnesium and calcium mass balances can be used to understand the 15 chemical fixation mechanisms in the sludge treatment system. However, in order to perform these balances, several assumptions must be taking into account:

- Phosphorus stored as Poly-P is hydrolised during anaerobic digestion (Wild et al., 1997).

- During Poly-P hydrolysis, the release of phosphorus is followed by a release of potassium and magnesium at the same ratio as it was observed during the phosphorus uptake (Jardin and Popel, 1994). Values of $0.354 \mathrm{gK} / \mathrm{gP}$ and $0.283 \mathrm{gMg} / \mathrm{gP}$ determined in previous studies (Barat et al., 2005) were used.

- Organic matter degradation produces a release of phosphorus (P), potassium (K), magnesium (Mg), and calcium (Ca) associated with the content of each element in the 
organic matter. This release must be quantified when the mass balances are performed.

- There is no chemical fixation of the potassium released in the digester due to the high concentration of ammonium reached in it. Only in the case of low ammonium concentrations, different authors (Schuiling and Andrade, 1999 and Wilsenach et al., 2006) have pointed out that potassium struvite (K-MAP, $\mathrm{KMgPO}_{4} \cdot 6 \mathrm{H}_{2} \mathrm{O}$ ) could precipitate instead of ammonium struvite (MAP).

According to the assumptions listed above, mass balances under steady state conditions can be carried out using the following equations:

- From the potassium mass balance (Eq. 1), the potassium released by polyphosphate accumulating organisms (PAO) (KPAOrel, M/T) can be calculated, considering that KoRGrel (M/T) represents the potassium released from organic matter degradation, $\mathrm{Q}_{\text {in }}$ and Qout $\left(\mathrm{L}^{3} / \mathrm{T}\right)$ the influent and effluent flow rates and $\mathrm{K}_{\text {in }}$ and $\mathrm{K}_{\text {out }}\left(\mathrm{L}^{3} / \mathrm{T}\right)$ the influent and effluent soluble potassium concentrations.

$$
\mathrm{K}_{\mathrm{PAO} \text { rel }}=\mathrm{K}_{\mathrm{TOTrel}}-\mathrm{K}_{\mathrm{ORGrel}}=\left(\sum \mathrm{Q}_{\text {out }} \cdot \mathrm{K}_{\text {out }}-\sum \mathrm{Q}_{\text {in }} \cdot \mathrm{K}_{\text {in }}\right)-\mathrm{K}_{\mathrm{ORGrel}}
$$

- The phosphate released by PAO (P PAOrel, M/T) can be calculated (Eq. 2) bearing in mind the mass of potassium released per mass of phosphate released. Then, from the phosphate mass balance, the phosphate fixed $\left(\mathrm{P}_{\text {fix }}(\mathrm{M} / \mathrm{T}) \% \mathrm{P}_{\text {fix }}\right)$ by precipitation or adsorption can be obtained (Eq. 3 and Eq. 4): being PorGrel (M/T) the amount of organic phosphate hydrolysed and $\mathrm{P}_{\text {in }}$ and $\mathrm{P}_{\text {out }}\left(\mathrm{M} / \mathrm{L}^{3}\right)$ the influent and effluent phosphate concentrations. 


$$
\begin{gathered}
\mathrm{P}_{\text {PAOrel }}=\mathrm{K}_{\text {PAOrel }} / 0.354 \\
\mathrm{P}_{\text {fix }}=\sum \mathrm{Q}_{\text {in }} \cdot \mathrm{P}_{\text {in }}+\mathrm{P}_{\text {ORGrel }}+\mathrm{P}_{\text {PAOrel }}-\sum \mathrm{Q}_{\text {out }} \cdot \mathrm{P}_{\text {out }} \\
\% \mathrm{P}_{\text {fix }}=\frac{\mathrm{P}_{\text {fix }}}{\sum \mathrm{Q}_{\text {in }} \cdot \mathrm{P}_{\text {in }}+\mathrm{P}_{\text {ORGrel }}+\mathrm{P}_{\text {PAOrel }}} \cdot 100
\end{gathered}
$$

- The magnesium mass balance can be applied in order to determine the magnesium precipitated (Mgprec, M/T and \%Mgprec) (Eq. 5 and Eq. 6) considering that MgPaOrel $(\mathrm{M} / \mathrm{T})$ represents the magnesium released by PAO, MgorGrel $(\mathrm{M} / \mathrm{T})$ the magnesium released by organic matter degradation, $\mathrm{Q}_{\text {in }}$ and $\mathrm{Q}_{\text {out }}\left(\mathrm{L}^{3} / \mathrm{T}\right)$ the influent and effluent flow rates and $\mathrm{Mg}_{\text {in }}$ and $\mathrm{Mg}_{\text {out }}\left(\mathrm{M} / \mathrm{L}^{3}\right)$ the influent and effluent soluble magnesium concentrations.

$$
\begin{gathered}
\mathrm{Mg}_{\text {prec }}=\sum \mathrm{Q}_{\text {in }} \cdot \mathrm{Mg}_{\text {in }}+\mathrm{Mg}_{\text {ORGrel }}+\mathrm{Mg}_{\text {PAOrel }}-\sum \mathrm{Q}_{\text {out }} \cdot \mathrm{Mg}_{\text {out }} \\
\% \mathrm{Mg}_{\text {prec }}=\frac{\mathrm{Mg}_{\text {prec }}}{\sum \mathrm{Q}_{\text {in }} \cdot \mathrm{Mg}_{\text {in }}+\mathrm{Mg}_{\text {ORGrel }}+\mathrm{Mg}_{\text {PAOrel }}} \cdot 100
\end{gathered}
$$

- Finally, the calcium precipitated (Caprec, $\mathrm{M} / \mathrm{T}$ and \%Caprec) can be obtained from the calcium mass balance (Eq. 7 and Eq. 8), being CaorGrel (M/T) the calcium release due to organic matter degradation, $\mathrm{Q}_{\text {in }}$ and $\mathrm{Q}_{\text {out }}\left(\mathrm{L}^{3} / \mathrm{T}\right)$ the influent and effluent flow rates and $\mathrm{Ca}_{\text {in }}$ and $\mathrm{Ca}_{\text {out }}\left(\mathrm{M} / \mathrm{L}^{3}\right)$ the influent and effluent soluble calcium concentrations.

$$
\begin{gathered}
\mathrm{Ca}_{\text {prec }}=\sum \mathrm{Q}_{\text {in }} \cdot \mathrm{Ca}_{\text {in }}+\mathrm{Ca}_{\text {oRGrel }}-\sum \mathrm{Q}_{\text {out }} \cdot \mathrm{Ca}_{\text {out }} \\
\% \mathrm{Ca}_{\text {prec }}=\frac{\mathrm{Ca}_{\text {prec }}}{\sum \mathrm{Q}_{\text {in }} \cdot \mathrm{Ca}_{\text {in }}+\mathrm{Ca}_{\text {ORGrel }}} \cdot 100
\end{gathered}
$$




\section{Results and discussion}

Table 1 shows the average values of the parameters analysed and the average flow rate for each line. Standard deviations are also provided.

\section{3.1. Influent wastewater}

As can be seen in Table 1, the influent wastewater characterization (line 1) showed high concentration of total phosphorus and phosphate (15.8 and $7.3 \mathrm{mgP} / \mathrm{l}$ respectively), soluble calcium (165.9 mg/l) and soluble magnesium (73.9 mg/l) which indicated the hardness of the water and suggested possible precipitation problems throughout the WWTP. Furthermore,

10 there was an important difference between total and soluble influent calcium concentration (201.6 and $165.9 \mathrm{mg} / \mathrm{l}$ respectively). This difference could be the result of calcium carbonate precipitation in the sewage network induced by the high influent alkalinity $(729 \mathrm{mgCaCO} / \mathrm{l})$.

\section{2. $P, K, M g$ and Ca content in the organic matter}

15 As it has been said before, $\mathrm{P}, \mathrm{K}, \mathrm{Mg}$ and Ca release due to organic matter hydrolysis should be considered to properly perform the mass balances. This makes it necessary to determined the $\mathrm{P}, \mathrm{K}, \mathrm{Mg}$ and $\mathrm{Ca}$ content in the primary sludge and in the excess sludge.

The amount of $\mathrm{P}, \mathrm{K}$, and $\mathrm{Mg}$ in the organic fraction of the primary sludge was estimated from experimental analysis (line 2, Table 1) assuming that suspended P, K, and Mg were mainly associated to organic matter. This assumption can be made because the presence of $\mathrm{P}, \mathrm{K}$ and Mg precipitates in the influent wastewater is negligible and no precipitation of $\mathrm{P}, \mathrm{K}$ and $\mathrm{Mg}$ is expected in the primary settler. Nevertheless, an accurately determination of the calcium content in the organic matter of primary sludge was not possible due to the high calcium carbonate concentration in the influent wastewater which is accumulated in the primary 
sludge. The obtained values for primary sludge (Table 2) were used to perform the mass balances in the gravity thickening units.

For the secondary sludge it is not possible to easily distinguish between the organic P, Mg,

5 and K content and that associated with Poly-P structure. Hence, reported values for biomass composition were assumed. These values (Table 2) were used to carry out the mass balances in the DAF thickening stage.

Once the organic $\mathrm{P}, \mathrm{K}, \mathrm{Mg}$, and Ca content in the primary and secondary sludge was

10 determined, the organic content of these elements in the mixed influent sludge (line 8) was calculated taking into account the proportion of primary and secondary sludge fed to the digester (i.e. 51\%-49\%, respectively).

\subsection{Mass balance across Murcia WWTP sludge line}

15 Mass balances for phosphate and soluble potassium, magnesium and calcium were performed under steady state conditions in different operation units, such as, gravity thickeners, secondary sludge DAF thickeners, anaerobic digesters and secondary digester.

\subsubsection{Gravity thickening}

20 As can be seen in Table 1, the soluble phosphorus, calcium, magnesium and potassium concentrations increased during the thickening process. No PAO presence was expected in gravity thickeners, so the organic release due to the solids degradation in the gravity thickener accounted for the increase in phosphate, magnesium and potassium concentrations. This organic matter degradation led to a release of $82.6 \mathrm{kgP} / \mathrm{d}, 21.4 \mathrm{kgMg} / \mathrm{d}$ and $26.7 \mathrm{kgK} / \mathrm{d}$. 
The phosphate and magnesium mass balances did not reveal a significant precipitation of these elements in the gravity thickener.

The calcium concentration raise was the most significant, increasing from $177.5 \mathrm{mgCa} / \mathrm{l}$, in

5 the primary sludge (line 2), to $1099.2 \mathrm{mgCa} / \mathrm{l}$ in the thickened sludge (line 4). The soluble calcium mass balance showed a release of $218.7 \mathrm{kgCa} / \mathrm{d}$. This high release may be put down not only to the organic release, as mentioned above, but also to a possible calcium carbonate dissolution forced by the $\mathrm{pH}$ decrease.

\subsubsection{DAF thickening}

Regarding the phosphorus dynamic in the DAF thickener, an important phosphate release took place in the thickened sludge. As can be seen in Table 1, the phosphate concentration increased significantly from $120.3 \mathrm{mgP} / \mathrm{l}$ in the excess sludge (line 5) to $1291.4 \mathrm{mgP} / \mathrm{l}$ in the floated sludge (line 7). The amount of phosphate released in the DAF thickener was 222.4 kgP/d: 206.9 kgP/d from Poly-P hydrolysis and only 15.5 kgP/d from organic matter degradation.

This phosphate release can be attributed to the formation of anaerobic zones inside the thickener. Under anaerobic conditions and in the presence of volatile fatty acids (VFA), PAO release the internal Poly-P to the bulk solution. These VFA are produced by the organic matter fermentation, which gives rise to a $\mathrm{pH}$ decrease as a consequence of the acid formation. This $\mathrm{pH}$ decrease was confirmed by the experimental $\mathrm{pH}$ values obtained during the analytical campaign. As can be seen in Table 1, the $\mathrm{pH}$ value decreased in the DAF thickener from 7.2 in the influent to 6.7 in the floated sludge. 
The soluble calcium concentration also increased in the DAF thickener. As can be seen in Table 1, the calcium concentration increased from $152.3 \mathrm{mg} / \mathrm{l}$ in the DAF influent (line 5) to $417.1 \mathrm{mg} / \mathrm{l}$ in the thickened sludge (line 7). The soluble calcium mass balance showed a release of $214.3 \mathrm{kgCa} / \mathrm{d}$. This release was mainly caused by the calcium carbonate dissolution

5 forced by the $\mathrm{pH}$ decrease during the organic matter fermentation since the organic matter degradation in the DAF thickeners is much lower than in the gravity thickeners.

Nevertheless, despite the high concentration of phosphate, calcium and magnesium achieved in the DAF thickener and according to the results obtained in the mass balances, no

10 precipitation was detected. The lack of precipitation probably stems from the sludge $\mathrm{pH}$ decrease in the DAF thickener, from 7.2 to 6.7 (See Table 1).

\subsubsection{Digestion}

The average organic loading rate (OLR) during the experimental period was 1.9 gTVS/l d.

15 The average value for TVS removal was 38\%, slightly lower than the typical values observed in the literature (Zhao and Viraraghavan, 2004). pH and alkalinity in the digester (Table 1) showed normal values for a well-stabilized digester. The redox potential was maintained around $-450 \mathrm{mV}$, which proves the important reducing conditions in the digester.

Table 3 shows the results of the mass balances carried out in the anaerobic digester. The

20 results obtained showed a lower release of phosphorus due to Poly-P hydrolysis $\left(\mathrm{P}_{\text {libPaO}}\right)$ than due to organic solids degradation ( $\mathrm{P}_{\text {libOrG }}$ ). This result confirmed that Poly-P degradation had begun in a previous stage of the sludge line. Considering that all the remaining Poly-P was released during the digestion process, the amount of Poly-P released in the digester (111.1 $\mathrm{kgP} / \mathrm{d}$ ) was lower than the amount of Poly-P released during the excess sludge thickening 25 (206.9 kgP/d). 
The mass phosphate balance showed an important precipitation of phosphate. The $50.7 \%$ of the available phosphate in the digester was fixed. Moreover, magnesium and calcium precipitation was detected. These results suggested that the conditions reached in the

5 digestion process enhanced the precipitation. The high concentration of ammonium (922.0 $\mathrm{mgNH}_{4}-\mathrm{N} / \mathrm{l}$ in the digested sludge versus $139.2 \mathrm{mgNH}_{4}-\mathrm{N} / \mathrm{l}$ before the digestion) and the increase in the $\mathrm{pH}$ value (from 6.8 to 7.5 ) during the anaerobic digestion process gave rise to the formation of struvite and in that stage of the sludge treatment line.

10 Finally, the results obtained in the secondary digester, using the experimental values showed in Table 1, confirmed that there was not more release of potassium from Poly-P. The magnesium and phosphate mass balances suggested a slight precipitation in the secondary digester.

\subsection{Distribution of precipitates in the digester}

According to the literature, four possible phosphate magnesium salts can precipitate from a solution containing $\mathrm{Mg}^{2+}, \mathrm{NH}_{4}{ }^{+}$, and $\mathrm{PO}_{4}{ }^{3-}$. These are: struvite $\left(\mathrm{MgNH}_{4} \mathrm{PO}_{4} \cdot 6 \mathrm{H}_{2} \mathrm{O}\right)$; magnesium hydrogen phosphate trihydrate or newberyite $\left(\mathrm{MgHPO}_{4} \cdot 3 \mathrm{H}_{2} \mathrm{O}\right)$; and trimagnesium phosphate in two states of hydration $\left(\mathrm{Mg}_{3}\left(\mathrm{PO}_{4}\right)_{2} \cdot 22 \mathrm{H}_{2} \mathrm{O}\right.$ and $\left.\mathrm{Mg}_{3}\left(\mathrm{PO}_{4}\right)_{2} \cdot 8 \mathrm{H}_{2} \mathrm{O}\right)$. These magnesium salts precipitate at different $\mathrm{pH}$ regions. Struvite precipitates at neutral and higher $\mathrm{pH}$ and at $\mathrm{Mg} / \mathrm{Ca}$ molar ratios $>6$; newberyite at $\mathrm{pH}<6$; trimagnesium phosphates, which are reported to have a low precipitation rate, have never been identified in the $\mathrm{pH}$ range $6<\mathrm{pH}<9$ (Musvoto et al., 2000). Also, precipitation of magnesite $\left(\mathrm{MgCO}_{3}\right)$ has not been considered due to its high solubility when compared to struvite. Therefore, struvite is the one that precipitates in the $\mathrm{pH}$ values achieved in anaerobic 
digesters. Moreover, as mentioned before, struvite deposits are quite common and actually found at just about every municipal WWTP where anaerobic digestion is carried out (Neethling and Benish, 2004). According to this, magnesium was considered to precipitate in the digester mainly as struvite, which made it possible to estimate the amount of phosphate 5 precipitated as struvite (\%P-MAP) from its stoichiometry.

Calcite precipitation was not considered due to the high phosphate concentrations in the digester. Several authors have reported that the presence of phosphates inhibits the calcite growth due to the adsorption of phosphates on the calcite surface enabling the formation of 10 calcium phosphates (Plant and House, 2002; Lin and Singer, 2005). Therefore, the calcium precipitated in the digester was considered to be in the form of calcium phosphates.

According to the Ostwald rule of stages, calcium phosphate formation takes place as a twostage process. In that process, the phases that are thermodynamically less stable (i.e.

15 precursors) are formed before the most stable phase, which is hydroxyapatite $\left(\mathrm{Ca}_{5}\left(\mathrm{PO}_{4}\right)_{3} \mathrm{OH}\right)$. Hence, hydroxyapatite (HAP) was considered as the calcium phosphate formed in this work due to the high process retention time, which let the precursors transform into HAP. Then, assuming that calcium precipitates with phosphate as HAP, it was calculated the amount of phosphate precipitated with calcium (\%P-HAP) using a molar ratio Ca/P of 1.67 . The rest of

20 the phosphorus fixed in the digester was considered to be adsorbed on the surface of solids $\left(\mathrm{P}_{\mathrm{ads}}\right)$. Although phosphate adsorption during anaerobic digester has not been completely understood, it is considered as a possible mechanism for phosphorus fixation (Jardin and Pöpel, 1994; Wild et al., 1997). 
The precipitation of aluminium and iron phosphates was not considered due to the negligible soluble iron and aluminium concentrations in the digester influent and effluent streams.

The results obtained showed that $52.0 \%$ of the phosphate precipitates as struvite, $39.2 \%$ as

5 hydroxyapatite and the remaining 8.8\% was adsorbed on solids surface. The magnesium mass balance in the secondary digester indicated a slight precipitation of phosphate as struvite.

In order to study the formation of struvite and hydroxyapatite at the digester conditions, the Saturation Index values (SI) for both precipitates were checked. The SI is used to describe the 10 saturation state of the aqueous phase composition versus different solids (Eq. 9). When SI = 0 the solution is in equilibrium; when SI $<0$ the solution is undersaturated and no precipitation occurs; when SI > 0 the solution is supersaturated and precipitation occurs spontaneously. Therefore, the SI values can be used to evaluate the effect of the solution conditions on the tendency and extent of the precipitation.

$$
\mathrm{SI}=\log \frac{\mathrm{IAP}}{\mathrm{K}_{\mathrm{SP}}}
$$

15 where IAP represents the ion activity product and $\mathrm{K}_{\mathrm{SP}}$ the thermodynamic solubility product.

As can be seen in Table 4 the digester sludge composition is supersaturated regarding MAP and HAP, confirming the possible formation of both precipitates in the digester. It can also be observed that the solution is supersaturated for the amorphous calcium phosphate (ACP).

20 This can be explained because ACP has been determined as one of the possible precursors of HAP formation. Regarding calcite formation, the results obtained in the geochemical study show that the solution is supersaturated for calcite. Nevertheless, as explained before, calcite formation was inhibited due to the high phosphate concentrations in the digester. 


\subsection{K-struvite precipitation}

The potential precipitation of K-struvite was evaluated through thermodynamic calculations according to the composition of the influent to the anaerobic digestion. The SI value was only evaluated in this line because in that point is where the concentration of phosphate,

5 magnesium and potassium achieved the higher values with low ammonium concentration. Therefore, this point shows the best conditions for K-struvite formation. The value of $\mathrm{K}_{\mathrm{SP}}$ used was $2.4 \cdot 10^{-11}$ for K-struvite (Taylor et al., 1963). Figure 3 shows the SI for K-struvite and for struvite in the influent line to anaerobic digestion at different $\mathrm{pH}$ (from 6.8 to 9.5). As can be seen, the influent sludge composition is undersaturated regarding K-struvite (SI = -

102.276 at $\mathrm{pH}=6.8$ ) not being expected its precipitation until K-struvite precipitation will be expected only at very high $\mathrm{pH}$ values. The SI values for struvite formation in this point show that the influent sludge composition is supersaturated for struvite formation in the entire $\mathrm{pH}$ interval studied. the elemental analysis of a precipitate sample (data not shown) showed the presence of calcium and magnesium without any trace of potassium. Finally, struvite

15 presence in the solid deposits found in the Murcia WWTP (Figure 2) was confirmed by means of XRD. Figure 4 shows the typical struvite diffraction peaks in the sample analysed.

\section{Conclusions}

Analytical determinations of soluble $\mathrm{P}, \mathrm{K}, \mathrm{Mg}$ and $\mathrm{Ca}$ and mass balances were used to easily identify precipitation problems throughout the sludge treatment line of Murcia Este WWTP.

The influent wastewater characterization showed the hardness of water and its potential to spontaneously precipitate different solids through the waste sludge treatment. 
The mass balances carried out in the DAF thickener and anaerobic digester showed that the higher amount of polyphosphate was released during the excess sludge thickening probably due to the formation of anaerobic zones inside the thickener. However, despite the high concentrations achieved in the thickened sludge, precipitation did not occur in this point due 5 to the $\mathrm{pH}$ decrease.

Precipitation problems were mainly found in the digestion stage. The $50.7 \%$ of the available phosphate was fixed in the digester: $52.0 \%$ precipitates as ammonium struvite, $39.2 \%$ precipitates as hydroxyapatite and the remaining $8.8 \%$ was adsorbed on the solids surface.

10 The increase in soluble $\mathrm{P}, \mathrm{K}, \mathrm{Mg}, \mathrm{NH}_{4}-\mathrm{N}$ and $\mathrm{Ca}$ availability in the digester as well as the $\mathrm{pH}$ increase were pointed out as the main factors causing precipitation problems.

Thermodynamic calculations and elemental analysis of a precipitate sample confirmed that K-struvite did not precipitate under the conditions achieved during the sludge treatment.

This study confirmed the important precipitation problems in the sludge management of a wastewater treatment plant with EBPR. Furthermore, it has been confirmed in other studies in different WWTP, that this problem is especially important in the Mediterranean Coast due to a significant saline intrusion in the sewage network which increases the magnesium content 20 in the influent wastewater.

The results obtained in this research will be use in future works to minimise phosphorus precipitation, reducing the maintenance problems associated, in Murcia Este WWTP. 
This research work has been supported by the Empresa Municipal de Aguas y Saneamiento de Murcia (EMUASA) which is gratefully acknowledged. 


\section{References}

American Public Health Association, American Water Works Association and Water Environmental Federation, 1998. Standard methods for the examination of water and wastewater, 20th edn, Washington DC, USA.

5

Barat, R.; Montoya, T.; Seco, A.; Ferrer, J., 2005. The role of potassium, magnesium and calcium in the enhanced biological phosphorus removal treatment plants. Environmental Technology, 26, 983-992.

10 Heinzmann, B.; Engel, G., 2005. Induced magnesium ammonia phosphate precipitation to prevent incrustations and measures for phosphate recovery. In Proceedings Nutrient Management in Wastewater Treatment Processes and Recycle Streams, Krakow.

Jardin, N.; Pöpel, H.J., 1994. Phosphate release of sludges from enhanced biological P-

15 removal during digestion. Water Science and Technology, 20(6), 281-292.

Lin Y.P.; Singer P. C., 2005. Inhibition of calcite crystal growth by polyphosphates. Water Research, 39, 4835-4843.

20 Mamais, D., Pitt, P.A, Cheng, Y.W., Loiacono, J., Jenkins, D., 1994. Determination of ferric chloride dose to control struvite precipitation in anaerobic sludge digester. Water Environ. Res, 912-918.

Metcalf \& Eddy, 2003. Wastewater Engineering: Treatment and reuse. $4^{\text {th }}$ Ed. McGraw Hill, 25 New York, USA. 
Musvoto, E.V.; Wentzel, M.C.; Ekama, G.A., 2000. Integrated chemical-physical processes modelling-II. Simulating aeration treatment of anaerobic digester supernatants. Water Research, 34, 1868-1880.

5 Neethling, J.B.; Benisch, M., 2004. Struvite control through process and facility design as well as operation strategy. Water Science and Technology 49(2), 191-199.

Nyberg, U.; Aspergren, H.; Andersson, B.; Elberg Jorgensen, P.; la Cour Jansen, J., 1994. Circulation of phosphorus in a system with biological P-removal and sludge digestion. Water 10 Science and Technology 30 (6), 293-302.

Ohlinger, K.N., Young, T.M., Schroeder, E.D., 1998. Predicting struvite formation in digestion, Water Research. 32, 3607-3614.

15 Parsons, S.A.; Doyle, J.D., 2004. Struvite scale formation and control. Water Science and Technology 49 (2), 177-182.

Plant, L.J.; House, W.A., 2002. Precipitation of calcite in the presence of inorganic phosphate. Colloids and Surfaces A: Physicochemical and Engineering Aspects, 203, $143-$ 20153.

Schuiling, R.D.; Andrade, A., 1999. Recovery of struvite from calf manure. Environmental Technology, 20 (7), 765-768.

25 Taylor, A.W.; Frazier, A.W.; Gurney, E.L., 1963. Trans. Faraday Soc. 59, 1580-1584. 
Wild, D.; Kisliakova, A.; Siegrist, H., 1997. Prediction of recycle phosphorus loads from anaerobic digestion. Water Research 31 (9), 2300-2308.

5 Wilsenach, J.; Schuurbiers, C.A.H.; van Loosdrecht, M.C.M., 2006. Phosphate and potassium recovery from source separated urine through struvite precipitation. Water Research, 41, 458466.

Zhao, H.W. and Viraraghavan, T, 2004. Analysis of the performance of an anaerobic

10 digestion system at the Regina wastewater treatment plant. Biores. Technol. 95, 815-819. 


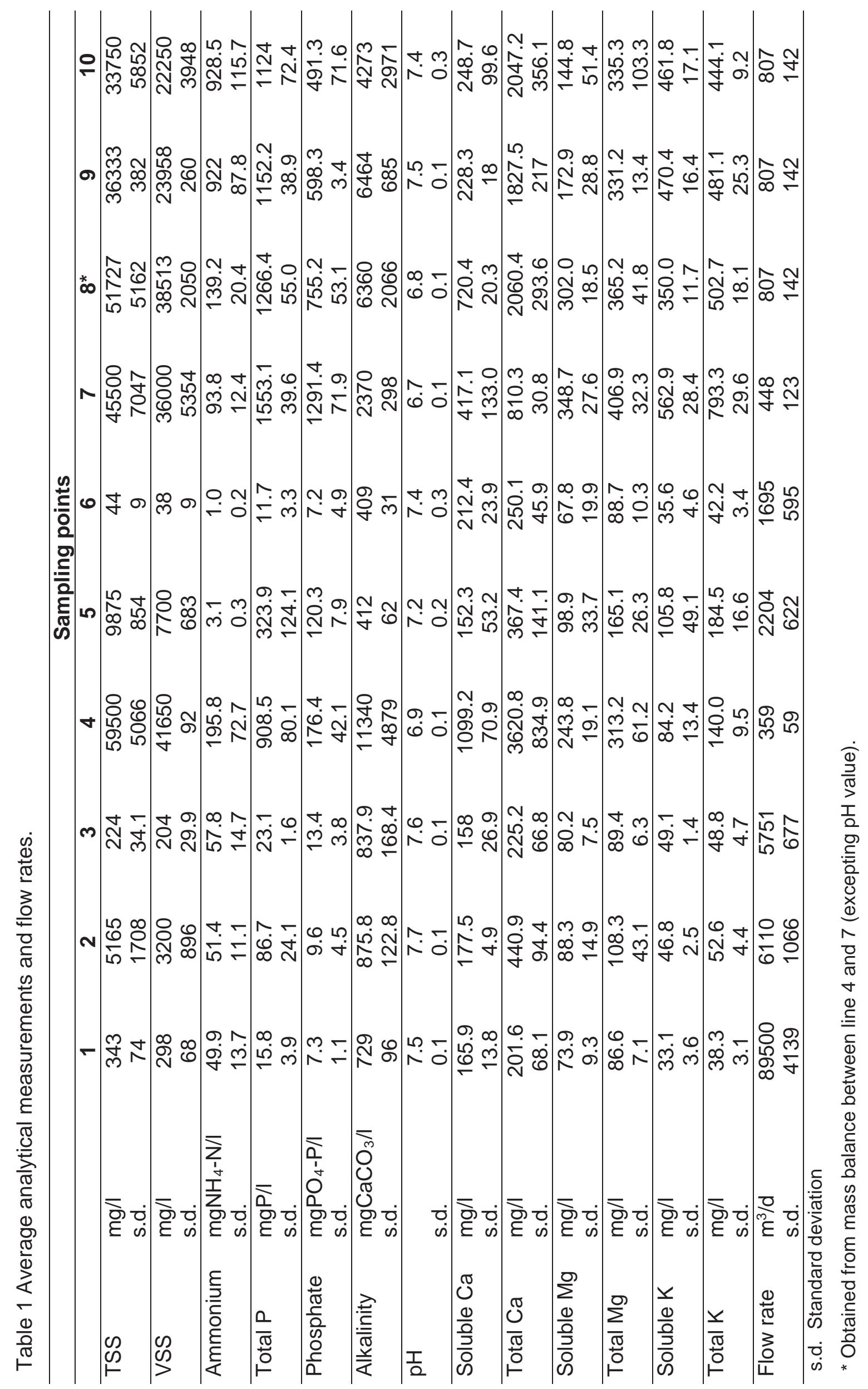


Table 2 Organic $\mathrm{P}, \mathrm{K}, \mathrm{Mg}$ and $\mathrm{Ca}$ in primary and secondary sludge.

\begin{tabular}{lcc}
\hline & Primary sludge $^{(\mathbf{a})}$ & Biomass $^{(\mathbf{b})}$ \\
\hline $\mathrm{P} \quad$ (mgP/mgTVS) & 0.024 & 0.020 \\
$\mathrm{~K}$ (mgK/mgTVS) & 0.002 & 0.008 \\
Mg (mgMg/mgTVS) & 0.006 & 0.004 \\
Ca (mgCa/mgTVS) & --- & 0.004 \\
\hline
\end{tabular}

(a) Experimental data

(b)Metcalf and Eddy (1995) 
Table 3 Results of the anaerobic digestor mass balances.

\begin{tabular}{|c|c|}
\hline $\begin{array}{l}\mathrm{K}_{\text {TOTrel }} \\
\mathrm{K}_{\text {ORGrel }} \\
\text { K}_{\text {PAOrel }} \\
\end{array}$ & $\begin{array}{ll}97.1 & \mathrm{kgK} / \mathrm{d} \\
57.8 & \mathrm{kgK} / \mathrm{d} \\
39.3 & \mathrm{kgK} / \mathrm{d} \\
\end{array}$ \\
\hline $\begin{array}{l}\text { P PAOrel } \\
\text { PORGrel }_{\text {Orix }} \\
\mathrm{P}_{\text {fix }} \\
\% P_{\text {fix }} \\
\end{array}$ & $\begin{aligned} 111.1 \mathrm{kgP} / \mathrm{d} \\
258.9 \mathrm{kgP} / \mathrm{d} \\
496.5 \mathrm{kgP} / \mathrm{d} \\
50.7 \% \\
\end{aligned}$ \\
\hline $\begin{array}{l}\text { MgpaOrel } \\
\text { MgorGrel } \\
\text { Mgprec } \\
\% g_{\text {prec }}\end{array}$ & $\begin{aligned} 39.3 \mathrm{kgMg} / \mathrm{d} \\
59.0 \mathrm{kgMg} / \mathrm{d} \\
202.5 \mathrm{kgMg} / \mathrm{d} \\
59.2 \%\end{aligned}$ \\
\hline $\begin{array}{l}\text { Ca orGrel } \\
\mathrm{Ca}_{\text {prec }} \\
\% \mathrm{Ca}_{\text {prec }} \\
\end{array}$ & $\begin{aligned} 22.9 \mathrm{kgCa} / \mathrm{d} \\
419.8 \mathrm{kgCa} / \mathrm{d} \\
69.5 \% \\
\end{aligned}$ \\
\hline $\begin{array}{l}\% \text { P-MAP } \\
\% \text { P-HAP } \\
\% \mathrm{P}_{\text {ads }}\end{array}$ & $\begin{array}{r}52.0 \% \\
39.2 \% \\
8.8 \%\end{array}$ \\
\hline
\end{tabular}


Figure 1. Deposits of precipitates: (a) sludge pipes, (b) struvite deposit

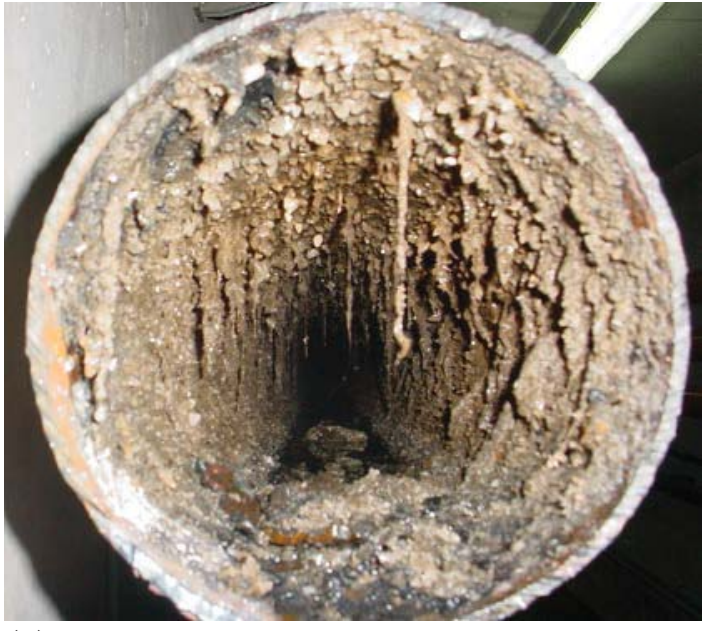

(a)

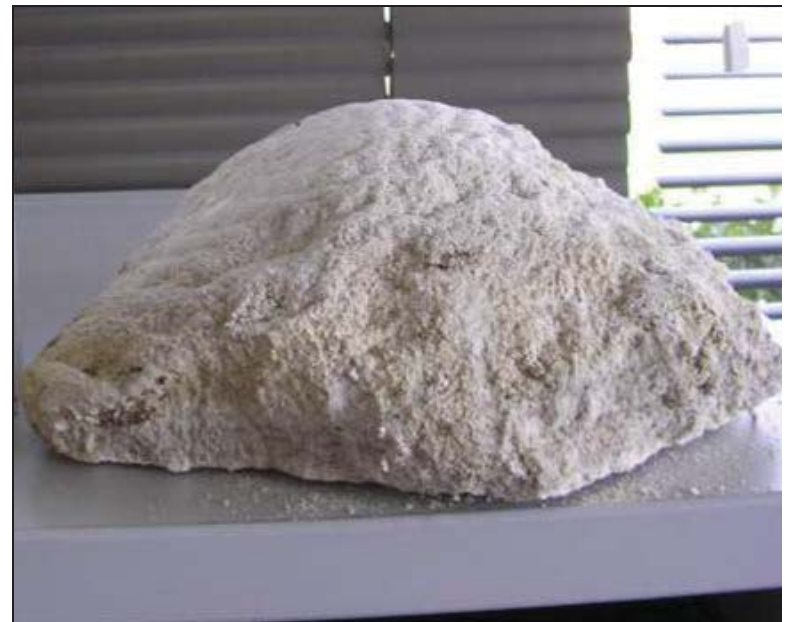

(b) 
Figure 2. Wastewater treatment plant flow chart and sampling points.

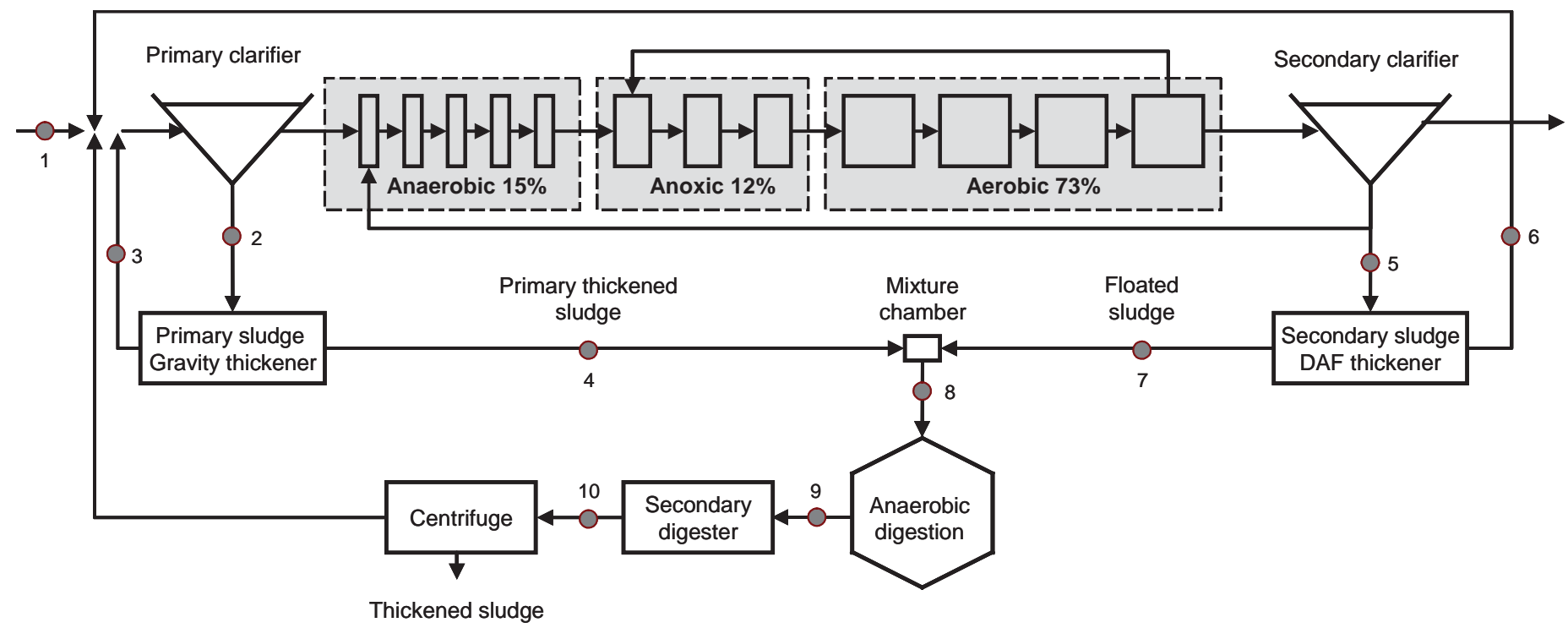


Figure 3. K-struvite and struvite SI in the influent line to anaerobic digestion at different $\mathrm{pH}$.

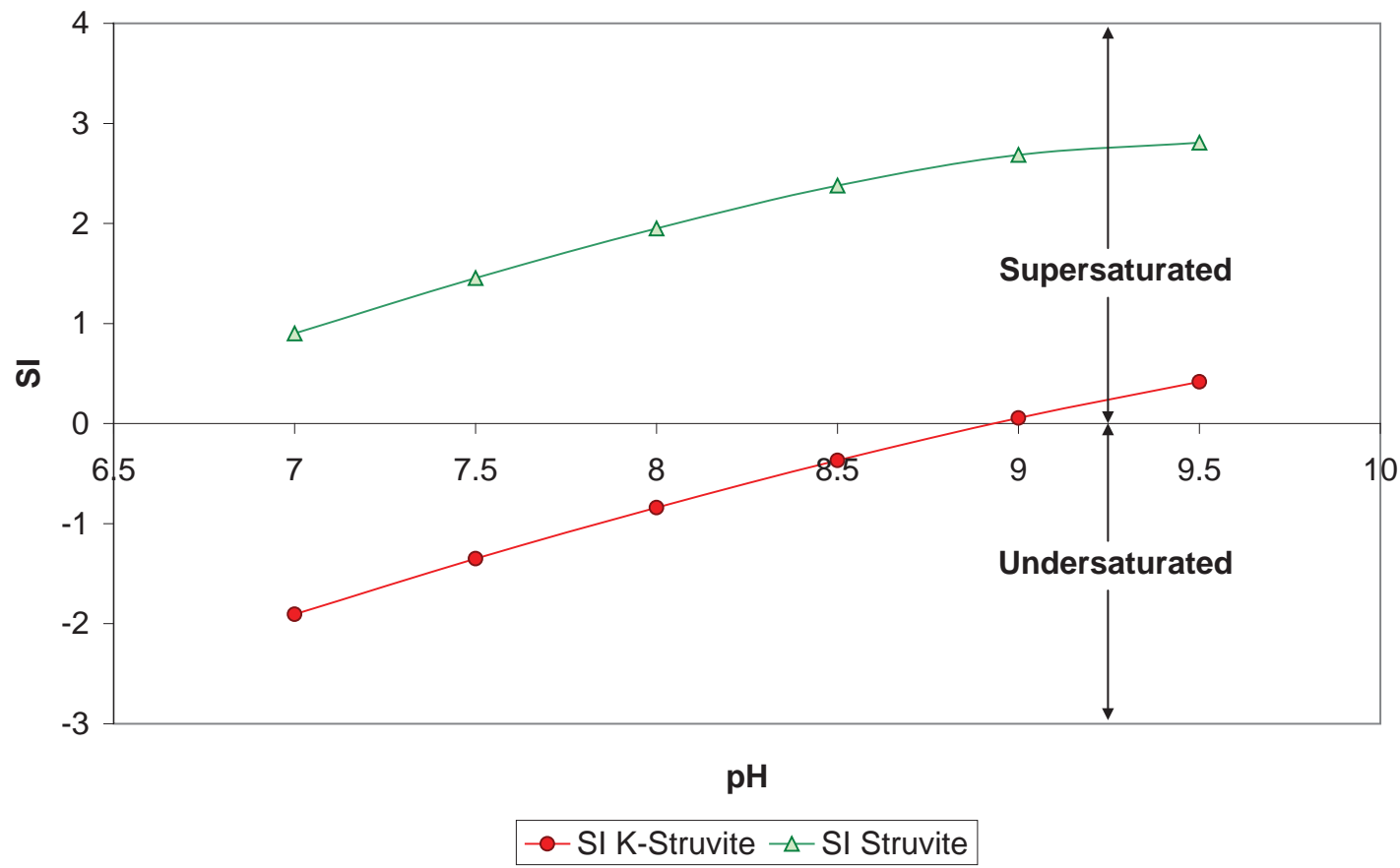


Figure 4. K-struvite SI in the influent line to anaerobic digestion at different $\mathrm{pH}$.

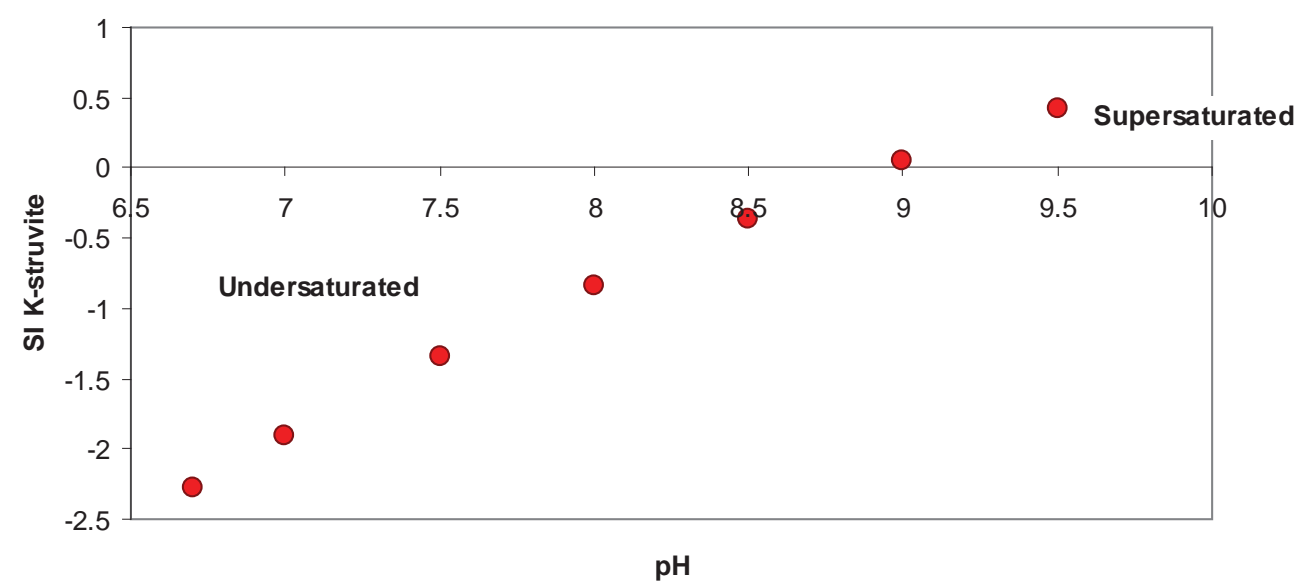

